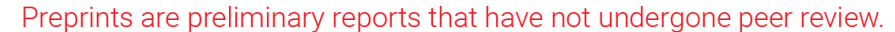 \\ They should not be considered conclusive, used to inform clinical practice, or referenced by the media as validated information. \\ First Evidence for Nicotiana (Tobacco) and its Human Use in Pleistocene North America
}

Daron Duke ( $\square$ daron@farwestern.com )

Far Western Anthropological Research Group https://orcid.org/0000-0001-8352-013X

\section{Eric Wohlgemuth}

Far Western Anthropological Research Group

\section{Karen Adams}

Crow Canyon Archaeological Center

\section{Angela Armstrong-Ingram}

Far Western Anthropological Research Group

\section{Sarah Rice}

HazAir

D. Young

Far Western Anthropological Research Group

\section{Article}

Keywords: Cultigens, Domestication Paths, Wishbone Site, Preservation Context, Hearth-side Activities, Deep-time Human Use, Plant Intoxicants

Posted Date: January 27th, 2021

DOI: https://doi.org/10.21203/rs.3.rs-139445/v1

License: (1) (i) This work is licensed under a Creative Commons Attribution 4.0 International License. Read Full License

Version of Record: A version of this preprint was published at Nature Human Behaviour on October 11th, 2021. See the published version at https://doi.org/10.1038/s41562-021-01202-9. 
1 First Evidence for Nicotiana (Tobacco) and its Human Use in Pleistocene North America

2 Daron Duke $^{1^{*}}$, Eric Wohlgemuth ${ }^{2}$, Karen R. Adams ${ }^{3}$, Angela Armstrong-Ingram ${ }^{2}$, Sarah K.

3 Rice $^{1}$, D. Craig Young ${ }^{4}$

$4 \quad{ }^{1}$ Far Western Anthropological Research Group, Desert Branch, Henderson, NV, USA

$5 \quad{ }^{2}$ Far Western Anthropological Research Group, Davis, CA, USA

$6 \quad{ }^{3}$ Crow Canyon Archaeological Center, Cortez, CO, USA

$7 \quad{ }^{4}$ Far Western Anthropological Research Group, Great Basin Branch, Carson City, NV, USA

$8 \quad$ * Corresponding author: daron@farwestern.com

10 Summary. Current studies on cultigens emphasize the protracted and intimate human

11 interactions with wild species that defined paths to domestication and, for certain plants,

12 profoundly impacted humanity ${ }^{1,2}$. Tobacco (Nicotiana) is one such plant. Tobacco arguably has

13 had more impact on global patterns in history than any other psychoactive substance, but how

14 deep its cultural ties trace back is widely debated. Adding to the puzzle is whether the

15 distribution of tobacco in North America occurred naturally or if humans themselves were

16 responsible for its expansion across the continent ${ }^{3}$. Archaeological excavations at the Wishbone

17 site, directed at the hearth-side activities of the early inhabitants of North America's desert west,

18 have uncovered evidence for tobacco approximately 12,300 years ago, 9,000 years earlier than

19 previously documented ${ }^{4}$. Here we detail the preservation context of the site, discuss its cultural

20 affiliation, and consider the ways that the tobacco may have been used. Researchers have long

21 suspected that human use extends earlier in time than can been readily demonstrated by such

22 fragile remains ${ }^{3-7}$, so the finding reinvigorates research on the driving cultural forces behind

23 tobacco's use, cultivation, and subsequent domestication. This has implications for our

24 understanding of deep-time human use of plant intoxicants, the intersection of non-food plant

25 domestication with that of food crops, and the trajectory of selective, potentially independent, 
26 interactions with tobacco from a broad cultural milieu in ancient North America to a place of

27 worldwide cross-cultural significance.

28 
Among the intoxicant plants preferred by humans, Nicotiana (tobacco) has perhaps had

30 the most significant social and economic impact. Its historical rise as a globally important

31 domesticate is directly tied to Western expansion and commerce, beginning with humble

32 interactions between Spanish explorers and native peoples in the Americas. Tobacco now

33 contributes to the enjoyment, traditional practice, and detriment of hundreds of millions of

34 people worldwide ${ }^{8}$. Within indigenous North American culture, ethnographic and historical

35 accounts indicate tobacco's use in all manner of ritual, medicinal, and social settings, and its

36 power is richly ensconced in oral traditions ${ }^{6,9-12}$. Of North America's desert west, the location of

37 the current study, the late tobacco specialist Joseph Winter" ${ }^{13}$ wrote: "Of all the native

38 groups...the Paiute, Goshute, Shoshone, Washo, Kawaiisu, and Ute of the Great Basin best

39 represent the ancient substratum of tobacco-using shamanism that evolved elsewhere

40 into...complex tobacco-using religious systems." This relationship implies deep time, but how

41 deep remains a vital question ${ }^{3-5,7,14,15}$.

42 Inextricably related is the question of whether people expanded the range of this

43 endemically South American plant across North America or if they found it distributed much as

44 today. Because archaeological material has so far been the only botanical indicator ${ }^{16,17}$,

45 distinguishing natural from cultural dispersal is challenging. Researchers have proposed several

46 hypotheses. One non-cultural possibility is that the widespread dispersal of tobacco was post-

47 Pleistocene, when warming and drying conditions allowed for natural expansion of wild tobacco

48 species from southern Mexico ${ }^{3,14}$. This timing post-dates the arrival of people, who appeared

49 south of the continental ice sheets in coastal and neighboring inland areas by at least 16,000

50 calibrated years before present (cal BP) ${ }^{18,19}$. Another hypothesis is that humans would have

51 recognized tobacco's intoxicant properties shortly after their arrival into southern continental 
52 regions, and having antecedent knowledge of other psychoactive plants, fostered its spread

53 northward by various means of transport, ground disturbance, and cultivation ${ }^{3}$. There are no

54 direct data to support these theories, and scholars have also worked back from the known

55 association of tobacco with a host of domesticated plants and agrarian economies ${ }^{17,20,21}$. Recent

56 finds of nicotine residue on smoking pipes provide the prior earliest demonstrated use of tobacco

57 at ca. 3,300 cal $\mathrm{BP}^{4}$. This is in a pre-agricultural context in the southeastern United States, where

58 the record of pipes, for tobacco or otherwise ${ }^{7}$, extends back to ca. 5,000 cal BP. Residues on

59 smoking pipes in the Pacific Northwest date to 1,200 cal BP or more ${ }^{7,15}$. In the Great Basin and

60 adjacent areas, where agriculture was never adopted, tobacco seeds have been found in cultural

61 contexts dating as early as ca. $1,750 \mathrm{cal} \mathrm{BP}^{22}$. If tobacco was available in western North America

62 when humans arrived, then there should be deep-time archaeological associations that further

63 narrow the period within which any human-based mechanisms of dispersal could play out.

\section{The Wishbone Site}

Archaeological excavations at the Wishbone site (42TO6384) have yielded evidence for

66 tobacco and its human use at approximately 12,300 cal BP ${ }^{23}$. Four charred Nicotiana seeds (Fig.

67 1) were found among the contents of an intact cultural hearth. The site is a hunter-gatherer camp

68 consisting of stone and bone artifacts surrounding the hearth and eroding from the mud flats of

69 the Great Salt Lake Desert (GSLD). The area is now an open playa, but the site is situated

70 alongside relict landforms of the Old River Bed Delta (ORBD) (Fig. 2), a once sprawling

71 marshland $\left(>1,000 \mathrm{~km}^{2}\right)$ that existed between approximately 13,000 to $9,500 \mathrm{cal} \mathrm{BP}^{24,25}$. During

72 this time, the ORBD served as a primary habitat draw for people in the region, who camped on

73 the intervening dry landforms between wetland water bodies. The dating of the site is based on

74 three radiocarbon age estimates on pieces of charred Salix sp. (willow) wood from the hearth fill, 
75 as detailed in Methods. These provide a combined radiocarbon age estimate for the hearth of

$7610,390 \pm 20 \mathrm{BP}$, which calibrates to a median probability age of 12,270 cal BP with a 95 percent

77 confidence range of $12,480-12,060$ cal BP. Willow was likely the best marshland fuelwood

78 option on the ORBD.

The site is culturally affiliated with an archaeological complex known as the Western

80 Stemmed technological tradition, within what is now native Shoshonean-speaking Goshute

81 territory. This tradition is largely restricted to western North America at the Pleistocene-

82 Holocene transition and is recognized by a series of stemmed projectile point styles, with the

83 oldest style, Haskett, identified among the hearth-associated artifacts at the Wishbone site.

84 Haskett points are lanceolate-shaped spear tips ${ }^{26,27}$ that date as early as $\sim 13,000 \mathrm{cal} \mathrm{BP}^{28}$. This

85 date is contemporaneous with the Clovis style, of the fluted point tradition, which is widely

86 recognized across the continent ${ }^{29}$. Haskett artifacts in dry shelter sites near the GSLD

87 demonstrate use in the area beginning sometime between 12,900 and 12,500 cal BP ${ }^{30,31}$. Both

88 Haskett and Clovis represent large-game hunting technologies used by highly mobile hunter-

89 gatherers, on the order of several hundred kilometers a year ${ }^{23,32,33}$, and the earliest

90 technologically distinctive cultural traditions in the sparsely populated continental interior ${ }^{34}$.

91 A diverse cultural assemblage is present at the site, providing behavioural context for the

92 find. Within the hearth fill, there were one of two Haskett point fragments, 586 burned waterfowl

93 bone fragments, three avian gastroliths (gizzard stones), and 10 pieces of stone toolmaking

94 debris. Surrounding the hearth, the excavation yielded over 20,000 fragments of waterfowl bone

95 food refuse (mostly Anatidae), various stone tools, additional toolmaking debris, a human-made

96 incised mammal bone object, the other half of the Haskett item from the hearth fill, and a

97 complete Haskett specimen (Fig. 3). Several of the bones exhibit tool cutmarks. A few medium- 
98 and large-mammal bone fragments were also found. All these materials were largely contained

99 within a three-meter radius but decreased substantially after one meter, a pattern common for

100 fireside activities.

101 The Nicotiana seeds were identified in 0.5-millimeter grade and 0.4-millimeter flotation

102 residues from the central hearth fill (Fig. 4). That they were preserved at all in such an early site

103 is attributed to the distinctive subsurface context of the GSLD. Geomorphological investigations

104 suggest the hearth had been buried by continued ORBD sediment deposition following the

105 Pleistocene habitation but before desiccation of the wetlands in the Early Holocene, ca. 9,500 cal

106 BP. Eolian and alluvial processes have been peeling sediment layers away since that time, just

107 now reaching the hearth. Beneath the ground surface, cultural deposits stay in a largely

108 undisturbed and sealed fine silty clay matrix. This matrix represents a waterlogged and nearly

109 anaerobic substrate ${ }^{35}$ that remains intact except at the deflating surface where wet-dry cycles and

110 seasonal water affect and destroy archaeological materials, and the wind carries away the

111 lightweight fragments. The hearth was being exposed at this erosional interface. The sediments

112 surrounding the hearth and similar Pleistocene-age paleoenvironmental control samples from the

113 site vicinity were also examined; no tobacco seeds were found, only the seeds of wetland plants.

114 Full macrobotanical results are presented in Methods.

115 Nicotiana is readily identifiable at the genus level, but species identification is

116 challenging given overlapping morphological attributes ${ }^{17,36-38}$. The Wishbone site seeds closely

117 resemble N. attenuata Torr. Ex S. Wats. (coyote tobacco), which in the Great Basin is both

118 common $^{17}$ and documented to have been tended by indigenous peoples ${ }^{10,13,39,40}$. The other

119 relevant regional species are N. quadrivalvis Pursh (Indian tobacco), and N. obtusifolia M.

120 Martens \& Galeotti (desert tobacco), formerly N. trigonophylla ${ }^{41}$. 


\section{Cultural versus Natural Deposition}

122 Seeds identified in prehistoric hearths usually represent human use unless attributable to

123 natural factors. We considered two alternative hypotheses to the interpretation that the Nicotiana

124 seeds were culturally deposited: 1) they represent the stomach contents of ducks cooked in the

125 hearth; and/or 2) they were included as a fire fuel source or were introduced naturally and

126 burned. To the first alternative, Nicotiana is not part of the avian diet. Nicotine and other

127 alkaloids are variably unpalatable and/or toxic to many vertebrate animal species ${ }^{42}$. Also,

128 regional Nicotiana is found upland in rocky outcrops and adjacent areas, in stark contrast to the

129 open marshland context—i.e., waterfowl food supply—of the ORBD and immediate site

130 vicinity. Nevertheless, we surmise that the internal organs of the cooked birds were present in the

131 hearth, so the possibility of incidental inclusion was addressed. Whole-bird cooking, a favored

132 method by native peoples in the region ${ }^{43}$, is suggested by the presence of gastroliths (gizzard

133 stones) and bones from the lower legs and feet, which were likely deposited from discarded

134 entrails and body parts. The hearth also contained Potamogeton spp. (pondweed) seeds, a

135 subaqueous dietary staple for many Anatidae species and an unlikely food target for people, in

136 relative abundance compared to our paleoenvironmental control samples.

137 Regarding the second alternative, Nicotiana's use by people as fuel is improbable

138 because tobacco is an annual or biennial plant lacking woody tissue that burns quickly and

139 cannot generate a fire of enough strength or duration for most cooking. Another incidental

140 possibility is from wildland fires, which presumes the presence of Nicotiana in the Pleistocene.

141 The local range of desert species of Nicotiana within its modern distribution can increase quickly

142 after wildfires, a fact exploited by Native people who sometimes used controlled burns to

143 enhance its yield ${ }^{10,13,36}$, but, human-induced or not, the plants would only be expected to expand 
144 within their normal habitat, not across the ORBD marshes. Possible tobacco habitat lies 13

145 kilometers to the northeast on Wildcat Mountain, a small, isolated mountain protruding from the

146 mud flats (Fig. 1). Otherwise, 24 kilometers separate the site to the nearest desert uplands at the

147 basin margin. Finally, we examined macrobotanical remains from our paleoenvironmental

148 control samples and found only seeds from plants common to Great Basin wetlands.

149 Potamogeton is more abundant in the hearth than the controls, supporting the case for duck

150 stomach contents, but there is no evidence for Nicotiana. Introduction of Nicotiana by natural

151 agents is not a parsimonious explanation for its presence at the Wishbone site.

\section{Manner of Human Use}

153 We cannot determine for certain the precise manner of human use for the tobacco at the

154 site, but there are a few considerations for narrowing down the range of possibilities. The data

155 suggest use as a fireside activity along with food preparation, consumption, and tool use among

156 mobile hunter-gatherers at distance from natural tobacco habitat. The finding of seeds implies

157 emphasis on leaves and flowering stems, the parts with the intoxicant effect. Seeds are the

158 tobacco parts preserved most often in the archaeobotanical record, but non-germinated seeds

159 carry no nicotine ${ }^{44}$. Because seeds are small and easily caught up by the sticky hairs of the plant,

160 they could be incidentally included when leaves and stems with attached flowering parts are

161 harvested. This is consistent with the archaeological record and preparation methods by native

162 groups in the Great Basin ${ }^{45,46}$.

163 The growing dataset of nicotine residues from precontact pipes indicates that tobacco

164 smoking was common $4,6,7,15,21$, but the chewing and/or sucking of plugs, pinches, and quids was

165 also practiced ${ }^{36,47}$. Smoking might introduce seeds by the discard of unused portions of undesired

166 dry remnants. Quids — wads of plant fiber containing tobacco to be chewed and/or sucked-have 
167 been found in regional dry caves and shelters. In on regional example, Arizona's Antelope Cave,

168 seeds and fragments of capsules, calyxes, pedicels, stems, and leaves were found in 90 percent of

169 the quids examined ${ }^{47}$. Seeds from quid use could have been deposited by being spat or by

170 expended quids being tossed into the fire.

171 Implications of Deep Time Tobacco Use

172 In the Great Basin, people lived as hunter-gatherers through Euroamerican contact, with

173 their most common foray into plant cultivation being with tobacco. At the Wishbone site, this

174 plant was brought from its upland habitat into the center of a large basin wetland early in the

175 human experience in the Americas. The data suggest that wild Nicotiana species were already

176 available consistent with their modern distribution when people arrived and begs the question of

177 whether tobacco's intoxicant properties were identified independently throughout the Americas.

178 The find recalibrates research on the adoption and eventual domestication of tobacco,

179 putting some 10,000 years of human use before the efflorescence of agriculture in North

180 America and the domestication of N. tabacum and N. rustica alongside a host of food crops. This

181 has important implications for examining how long-term cultural relationships with intoxicants

182 shape and respond to further developments. Tobacco's early use lends to the interpretation that

183 there is nothing inevitable about domestication. Rather, tobacco's long heritage with humans,

184 entailing both use and abuse, represents one view from the sociocultural side of an intensification

185 process that manifest itself differently according to local socioeconomic incentives and

186 pressures. With its rich history in Western commerce, influence, and cross-cultural impact,

187 tobacco is uniquely suited to examining this process through a connection to many societal facies

188 since the Pleistocene. 
191 1. Allaby, R. G., Fuller, D. Q. \& Brown, T. A. The genetic expectations of a protracted model for the origins of domesticated crops. Proceedings of the National Academy of Sciences of the United States of America 105, 13982-13986 (2008).

2. Larson, G. et al. Current perspectives and the future of domestication studies. Proceedings of the National Academy of Sciences of the United States of America 111, 6139-6146 (2014).

3. Winter, J. C. Food of the Gods: Biochemistry, Addiction, and the Development of Native American Tobacco Use. in Tobacco Use by Native North Americans: Sacred Smoke and Silent Killer 305-328 (University of Oklahoma Press, 2000).

4. Carmody, S. et al. Evidence of tobacco from a Late Archaic smoking tube recovered from the Flint River site in southeastern North America. Journal of Archaeological Science: Reports 21, 904-910 (2018).

5. Fitzpatrick, S. M. \& Merlin, M. D. Introduction: Drugs from a Deep Time Perspective. in Ancient Psychoactive Substances (ed. Fitzpatrick, S. M.) 1-19 (University Press of Florida, 2018).

6. Rafferty, S. M. Prehistoric Intoxicants of North America. in Ancient Psychoactive Substances (ed. Fitzpatrick, S. M.) 112-127 (University Press of Florida, 2018).

7. Tushingham, S., Snyder, C. M., Brownstein, K. J., Damitio, W. J. \& Gang, D. R. Biomolecular archaeology reveals ancient origins of indigenous tobacco smoking in North American Plateau. Proceedings of the National Academy of Sciences of the United States of America 115, 11742-11747 (2018).

8. WHO Report on the Global Tobacco Epidemic, 2019. https://www.who.int/teams/healthpromotion/tobacco-control/who-report-on-the-global-tobacco-epidemic-2019 (2019).

9. Perspectives on the Archaeology of Pipes, Tobacco and other Smoke Plants in the Ancient Americas. (Springer International Publishing, 2016). doi:10.1007/978-3-31923552-3.

10. Fowler, C. S. Subsistence. in Handbook of North American Indians: Great Basin, Volume 11 (ed. D’Azevedo, W. L.) 64-97 (Smithsonian Institute, 1986).

11. Turner, N. J. \& Taylor, R. L. A Review of the Northwest Coast Tobacco Mystery. Syesis 5, 249-257 (1972).

12. Tobacco Use by Native North Americans: Sacred Smoke and Silent Killer. (University of Oklahoma Press, 2000).

13. Winter, J. C. Traditional Uses of Tobacco by Native Americans. in Tobacco Use by Native North Americans: Sacred Smoke and Silent Killer (ed. Winter, J. C.) 9-58 (University of Oklahoma Press, 2000).

14. Goodspeed, T. H. The Genus Nicotiana: Origins, Relationships, and Evolution of its Species in the Light of Their Distribution, Morphology, and Cytogenetics. (Chronica Botanica, 1954).

15. Tushingham, S. et al. Hunter-gatherer tobacco smoking: earliest evidence from the Pacific Northwest Coast of North America. Journal of Archaeological Science 40, 13971407 (2013).

16. Särkinen, T., Bohs, L., Olmstead, R. G. \& Knapp, S. A phylogenetic framework for evolutionary study of the nightshades (Solanaceae): A dated 1000-tip tree. BMC

Evolutionary Biology 13, (2013). 
17. Winter, J. C. Botanical Description of the North American Tobacco Species. in Tobacco Use by Native North Americans: Sacred Smoke and Silent Killer (ed. Winter, J. C.) 87-

18. Davis, L. G. et al. Late Upper Paleolithic occupation at Cooper's Ferry, Idaho, USA, $\sim 16,000$ years ago. Science 897, 891-897 (2019).

19. Waters, M. R. Late Pleistocene exploration and settlement of the Americas by modern humans. Science 365, (2019).

20. Wagner, G. E. Tobacco in Prehistoric Eastern North America. in Tobacco Use by Native North Americans: Sacred Smoke and Silent Killer (ed. Winter, J. C.) 185-201 (University of Oklahoma Press, 2000).

21. Raffety, S. M. Evidence of early tobacco in Northeastern North America? Journal of Archaeological Science 33, 453-458 (2006).

22. Arkush, B. S. \& Arkush, D. Aboriginal plant use in the central Rocky Mountains: Macrobotanical records from three prehistoric sites in Birch Creek Valley, eastern Idaho. North American Archaeologist (2020) doi:10.1177/0197693120967005.

23. Duke, D., Rice, S. K., Young, D. C. \& Byerly, R. The Playas Archaeological Inventory: 6,914 Acres on the Utah Test and Training Range Including Portions of the West Distal Delta of the Old River Bed and Test Excavations at the Wishbone Site (42TO6384), Tooele County, Utah. (2018).

24. Duke, D. G. If the Desert Blooms: A Technological Perspective on Paleoindian Ecology in the Great Basin from the Old River Bed, Utah. Department of Anthropology (University of Nevada, Reno, 2011).

25. Madsen Dave N. Schmitt, and David Page, D. B. The Paleoarchaic Occupation of the Old River Bed Delta. University of Utah Anthropological Papers 128 (The University of Utah Press, 2015).

26. Smith, G. M. et al. The Western Stemmed Tradition: Problems and Prospects in Paleoindian Archaeology in the Intermountain West. PaleoAmerica 6, 23-42 (2020).

27. Duke, D. Haskett Spear Weaponry and Protein-Residue Evidence of Proboscidean Hunting in the Great Salt Lake Desert, Utah. PaleoAmerica 1, 109-112 (2015).

28. Jenkins Loren G. Davis, Thomas W. Stafford Jr., Paula F. Campos, Bryan Hockett, George T. Jones, Linda Scott Cummings, Chad Yost, Thomas J. Connolly, Robert M. Yohe, Summer C. Gibbons, Maanasa Raghavan, Morten Rasmussen, Johanna L.

Paijmans, Michael Hofr, D. L. Clovis Age Western Stemmed Projectile Points and Human Coprolites at the Paisley Caves. Science 337, 223-228 (2012).

29. Waters, M. R., Stafford, T. W. \& Carlson, D. L. The age of Clovis-13,050 to 12,750 cal yr B.P. Science Advances 6, 1-12 (2020).

30. Bryan, A. L. Smith Creek Cave. in The Archaeology of Smith Creek Canyon, Eastern Nevada (ed. Touhy and D. L. Randall, D. R.) 162-253 (Nevada State Museum Anthropological Papers 17, 1979).

31. Goebel, T. \& Keene, J. L. Are Great Basin Stemmed Points as Old as Clovis in the Intermountain West? A Review of the Geochronological Evidence. in Archaeology in the Great Basin and Southwest: Papers in Honor of Don D. Fowler (eds. Parezo, N. J. \& Janetski, J. C.) 35-60 (The University of Utah Press, 2014).

32. Jones Charlotte Beck, Eric E. Jones, Richard E. Hughes, G. T. Lithic Source Use and Paleoarchaic Foraging Territories in the Great Basin. American Antiquity 68, 5-38 (2003). 
33. Kilby, J. D. An Investigation of Clovis Caches: Content, Function, and Technological Organization. Department of Anthropology vol. Ph.D. (University of New Mexico, 2008).

34. Beck and George. T. Jones, C. Clovis and Western Stemmed: Population Migration and the Meeting of Two Technologies in the Intermountain West. American Antiquity 75, 81116 (2010).

35. Holden, J. et al. Hydrological controls of in situ preservation of waterlogged archaeological deposits. Earth-Science Reviews 78, 59-83 (2006).

36. Adams, K. R. \& Toll, M. S. Tobacco Use, Ecology, and Manipulation in the Prehistoric and Historic Southwestern United States. in Tobacco Use by Native North Americans: Sacred Smoke and Silent Killer (ed. Winter, J. C.) 143-170 (University of Oklahoma Press, 2000).

37. Gunn, C. R. \& Gaffney, F. B. Seed Characteristics of 42 Economically Important Species of Solanaceae in the United States. (United States Department of Agriculture, 1974).

38. Winter, J. C. Introduction to North American Tobacco Species. in Tobacco Use by Native North Americans: Sacred Smoke and Silent Killer (ed. Winter, J. C.) 3-8 (University of Oklahoma Press, 2000).

39. Adams, K. R. Prehistoric Reedgrass (Phragmites) "Cigarettes" with Tobacco (Nicotiana) Contents: a Case Study from Red Bow Cliff Dwelling, Arizona. Journal of Ethnobiology 10, 123-139 (1990).

40. Rhode, D. Native Plants of Southern Nevada. (University of Utah Press, 2002).

41. Makings, E. \& Solves, J.-P. Solanaceae Part Six: Nicotiana L. Tobacco. Canotia 14, 5462 (2018).

42. Aniszewski, T. Alkaloids: Chemistry, Biology, Ecology, and Applications. (Elsevier Science, 2015).

43. Fowler, C. S. In the Shadow of Fox Peak: An Ethnography of the Cattail-Eater Northern Paiute People of Stillwater Marsh. (United States Department of the Interior, Fish and Wildlife Service, Region 1, Stillwater National Wildlife Refuge. Cultural Resource Series $5,1992)$.

44. Tso, T. C. \& Jeffrey, R. N. Studies in Tobacco Alkaloids. I. Changes in Nicotine and Nornicotine Content in Nicotiana. Plant Physiology 31, 433-440 (1956).

45. Murphey, E. V. A. Indian Uses of Native Plants. (Desert Printers, Inc., 1959).

46. Zigmond, M. L. Kawaiisu. in Handbook of North American Indians: Great Basin, Volume 11 398-411 (Smithsonian Institution, 1986).

47. Adams, K. R., Johnson, K. L. \& Murphy, T. M. Prehistoric Puebloan yucca (Yucca) quids with wild tobacco (Nicotiana) contents: Molecular and morphological evidence from Antelope Cave, northwestern Arizona. Journal of Field Archaeology 40, 310-324 (2015).

48. Wohlgemuth, E. Appendix H: Archaeobotanical Remains. in Prehistory of the Sacramento River Canyon, Shasta County, California (eds. Basgall, M. E. \& Hildebrandt, W. R.) (Center for Archaeological Research, 1989).

49. Pearsall, D. M. Paleoethnobotany: A Handbook of Procedures. (Routledge, 2015).

50. Reimer, P. J. et al. The IntCal20 Northern Hemisphere Radiocarbon Age Calibration Curve (0-55 cal kBP). Radiocarbon 62, 725-757 (2020).

51. Ramsey, C. B. Bayesian Analysis of Radiocarbon Dates. Radiocarbon 51, 337-360 (2009). 
A
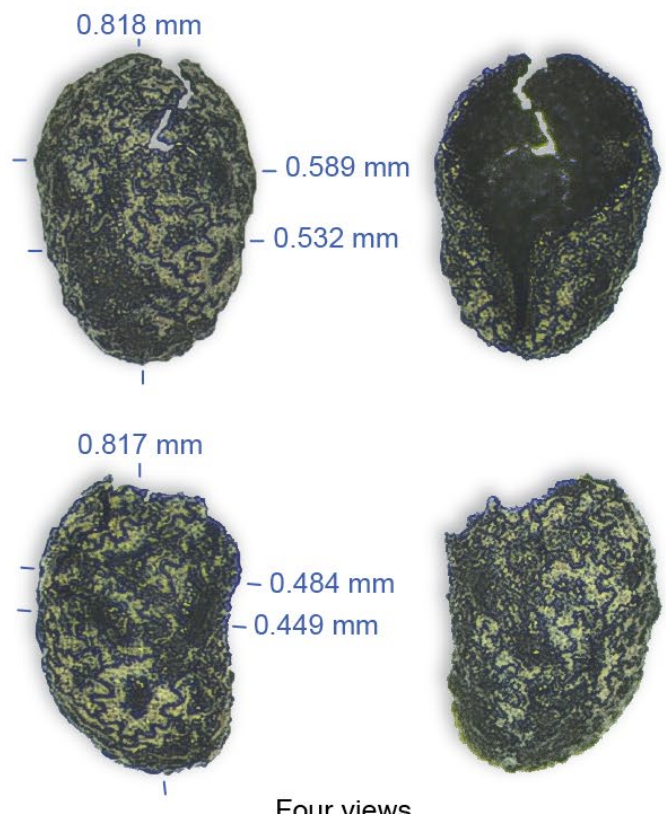

327

328

329 Fig. 1. Nicotiana seeds and measurements from the Wishbone site. (A) Specimen 1-35-98-1. (B)

330 Specimen 1-40-98-2. (C) Specimen 1-40-98-1. (D) Specimen 2-40-98-1.
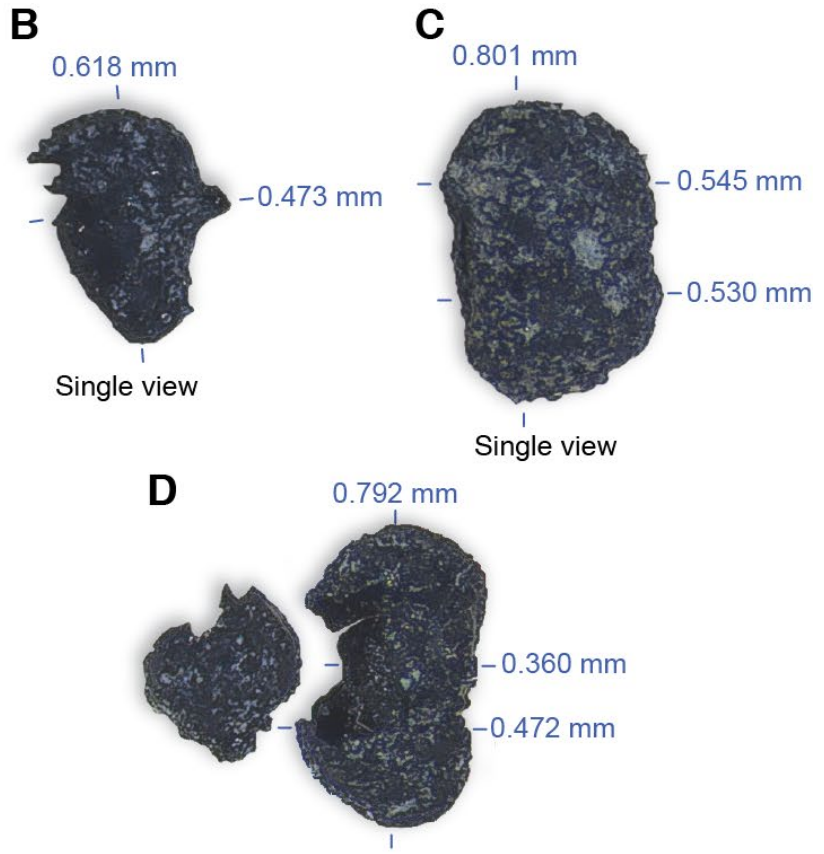

Single view 


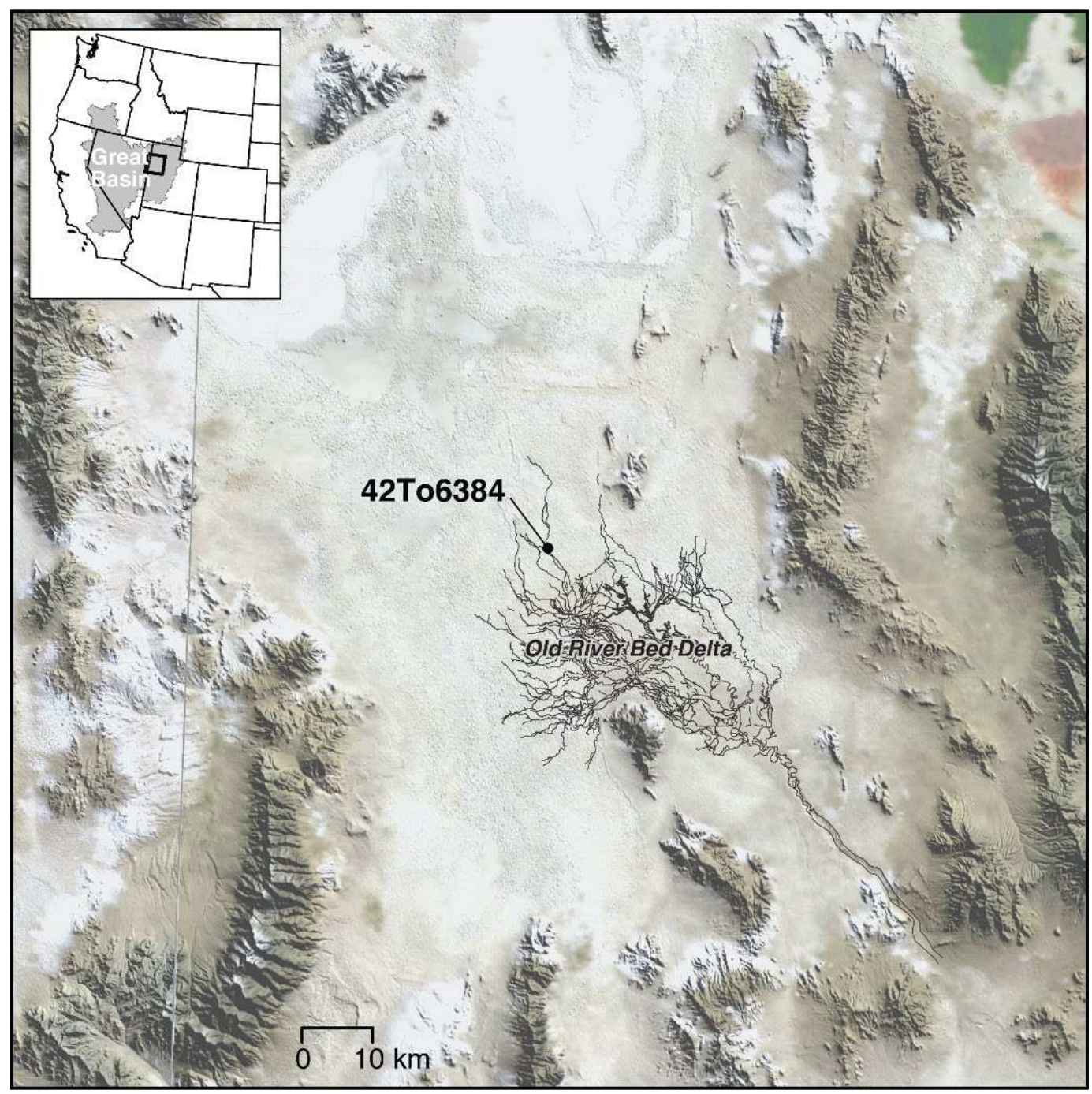

332 Fig. 2. Location of 42 TO6384 and important physiographic features. The ORBD channels are

333 based on GIS mapping of extant landforms using aerial imagery (courtesy U.S. Army Dugway

334 Proving Ground). 


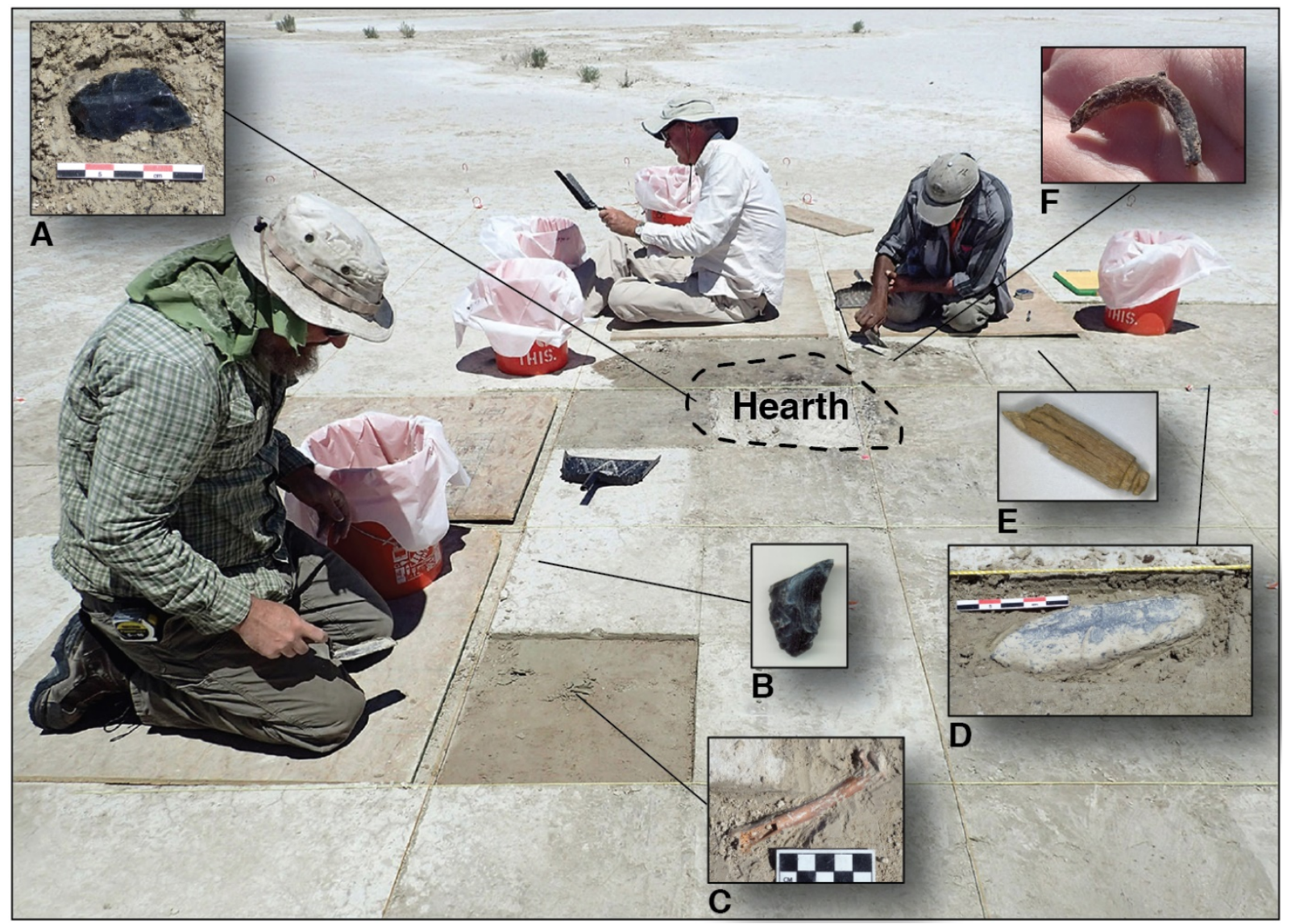

337 Fig. 3. Position of hearth (circled) relative to selected artifacts at the Wishbone site. (A) Haskett

338 fragment, FS 247, refits with FS 59. (B) Haskett fragment, FS 59, refits with FS 247. (C)

339 Anatidae humerus, FS 230. (D) Haskett, FS 220. (E) incised mammal bone, FS 761. (F) Anatidae 340 furculum, FS 230. 


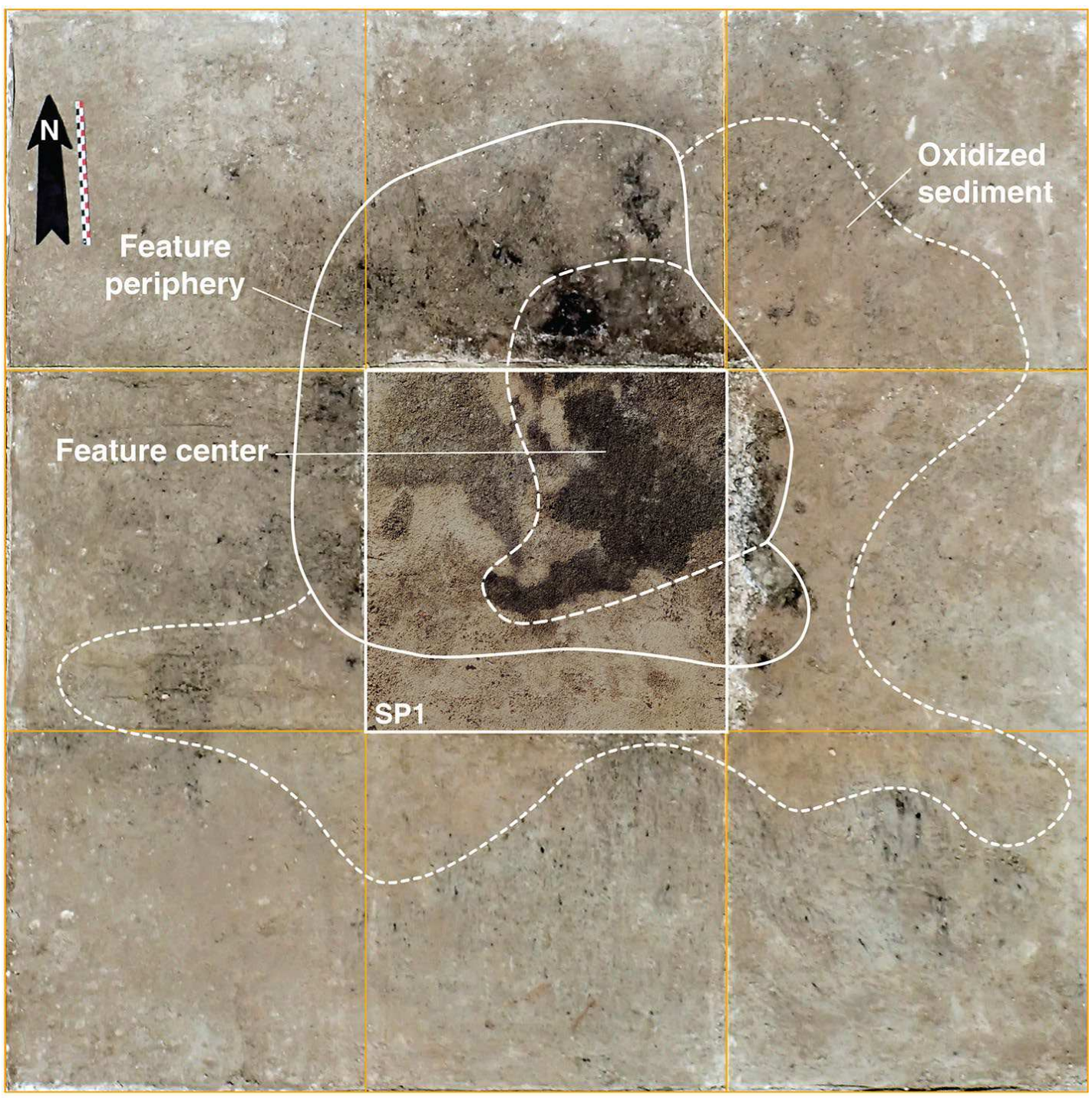

342 Fig. 4. Hearth (Feature 1) plan view. View is at $2 \mathrm{~cm}$ below the ground surface $(162 \mathrm{~cm}$ below

343 datum). Central square represents the $0.5-\mathrm{x}-0.5-\mathrm{m}$ shovel probe (SP1) excavated and

344 photographed in 2015. The Nicotiana seeds were found in the flotation-processed feature center

345 fill from SP1. Remaining area excavated to the same level and photographed in 2016. Charcoal

346 flecks outside the defined hearth boundary likely represent windblown pieces from the time of

347 use. 
Macrobotanical specimens were identified in the laboratory from sediment fill collected

350 during site excavations (Extended Data Table 1). The hearth extended approximately two

351 centimeters down from the ground surface. All excavated sediment within a 3-x-3-m gridded

352 area inclusive of and surrounding the hearth was bagged by $0.5-\mathrm{x}-0.5-\mathrm{m}$ subunit for

353 comprehensive analysis in the laboratory. Artifacts were piece plotted when encountered to

354 document their spatial association with the hearth.

Paleoenvironmental control samples from seven geo-localities in the vicinity $(<3 \mathrm{~km})$ of

356 the site were collected for comparison to the hearth contents. These are of similar age to the site

357 and intended to represent the macrobotanically identifiable plant profile of the ORBD wetlands

358 at the Pleistocene-Holocene transition. The sediments, often referred to as "black mats," are

359 extant shallow-marsh, organic-rich sediment layers that retain a black-to-gray color. While bulk

360 organic sediments can only represent an average of time, their deposition on the ORBD tended to

361 occur in short-lived oscillations of wetland waterways. They have proven useful in radiocarbon

362 dating of the ORBD system ${ }^{24,25}$ (Duke 2011; Madsen et al. 2015), and their age resolution is

363 sufficient for current purposes.

The sediment samples were flotation-processed using a manual technique utilized for

365 thousands of soil samples throughout the Great Basin and California ${ }^{48,49}$ (Wohlgemuth 1989;

366 Pearsall 2015). Three iterations of filling, skimming, and decanting from the slurry in a washtub

367 ensured thorough recovery collection of charred plant remains in the buoyant light fraction

368 collected using $0.4-\mathrm{mm}$ screen. The approximately $1.0-\mathrm{mm}$ tobacco seeds and other small plant

369 specimens would be caught in this mesh. The non-buoyant heavy fraction was washed through 3-

$370 \mathrm{~mm}$ and $0.7-\mathrm{mm}$ mesh to retrieve other fine-grained site constituents as well as the rare non- 
371 buoyant plant remains. Thorough washing of all equipment, prior to and upon completion of

372 flotation, ensured that no inter-sample contamination occurred. Light fraction was size-sorted

373 using 2-mm, 1-mm, 0.7- $\mathrm{mm}$, and 0.5-mm mesh. Sorting of light fractions for charred seeds and

374 other recognizable plant material was then completed. Each size grade, including the 0.4-mm

375 residue, was examined under a microscope at 10-30x magnifications. Soil volume (L) and weight

$376(\mathrm{~kg})$ were recorded for each flotation sample.

377 Radiocarbon dating by Accelerator Mass Spectrometry (AMS) was conducted on charred

378 woody material from the hearth contents, retrieved during manual flotation, and on six of the

379 seven the paleoenvironmental control localities (Extended Data Table 2). The Nicotiana seeds

380 were judged too small $(<0.1 \mathrm{mg})$ and fragile for direct dating by current methods. The charred

381 wood samples were submitted to the Paleoscapes Archaeobotanical Services Team for plant

382 identification before submission to Beta Analytic for AMS dating. Age calibrations are based on

383 the IntCal20 curve $^{50}$ (Reimer et al. 2020) via OxCal $4.4^{51}$ (Ramsey 2009). The calibrated median

384 probability age for the site was generated using the OxCal combining tool. 


\section{References (Methods)}

386 Included in above References section

387 


\begin{tabular}{|c|c|c|c|c|c|c|c|c|c|c|c|c|}
\hline Site & & & $42 \mathrm{TO6384}$ & $42 \mathrm{TO6384}$ & $42 \mathrm{TO6384}$ & - & - & - & - & - & - & - \\
\hline Geo-locality & & & To64-1 & & $\mathbf{n} / \mathbf{a}$ & To27-1 & $\begin{array}{l}\text { To35-1, -2, } \\
-3,-4,-5\end{array}$ & To65-1 & To66-1 & To81-4 & To85-8 & To114-1 \\
\hline Sediment Context & & & $\begin{array}{l}\text { Within } \\
\text { hearth (fill) }\end{array}$ & $\begin{array}{l}\text { Beneath } \\
\text { hearth }\end{array}$ & $\begin{array}{l}\text { Outside } \\
\text { hearth }\end{array}$ & $\begin{array}{l}\text { Organic } \\
\text { sediment }\end{array}$ & $\begin{array}{l}\text { Organic } \\
\text { sediment }\end{array}$ & $\begin{array}{l}\text { Organic } \\
\text { sediment }\end{array}$ & $\begin{array}{l}\text { Organic } \\
\text { sediment }\end{array}$ & $\begin{array}{l}\text { Organic } \\
\text { sediment }\end{array}$ & $\begin{array}{l}\text { Organic } \\
\text { sediment }\end{array}$ & $\begin{array}{l}\text { Organic } \\
\text { sediment }\end{array}$ \\
\hline Volume (I) & & & 12.1 & 23.3 & 327.9 & 2.3 & 35.2 & 0.15 & 0.5 & 1.8 & 19.5 & 2.5 \\
\hline Scientific name & Common name & & & & & & & & & & & \\
\hline Calandrinia spp. & Red maids & ct & 1 & - & - & - & - & - & - & - & - & - \\
\hline $\begin{array}{l}\text { Chenopodium } \\
\text { berlandieri }\end{array}$ & Pitseed goosefoot & ct & 5 & - & - & - & - & - & - & - & - & - \\
\hline Chenopodium spp. & Goosefoot & ct & - & - & - & - & 11 & - & - & - & - & - \\
\hline Deschampsia spp. & Hairgrass & ct & 3 & - & - & - & - & - & - & - & 2 & - \\
\hline Juncus spp. & Rush & ct & 4 & 1 & - & - & - & - & - & - & 1 & - \\
\hline Nicotiana spp. & Tobacco & ct & 4 & - & - & - & - & - & - & - & - & - \\
\hline Potamogeton spp. & Pondweed & ct & 44 & - & 20 & - & 3 & - & - & - & - & - \\
\hline Rumex spp. & Dock & ct & - & - & - & 1 & - & - & - & - & 1 & - \\
\hline Schoenoplectus spp. & Tule & ct & 75 & 6 & 67 & 99 & 94 & 2 & 4 & 2 & 133 & 57 \\
\hline Typha spp. & Cattail & ct & - & - & 1 & 4 & - & - & - & - & 23 & - \\
\hline Chenopodiaceae & Goosefoot family & ct & 1 & - & 3 & 1 & - & - & - & 8 & 66 & 9 \\
\hline Poaceae fragments & Grass family & ct & 11 & 1 & 4 & 2 & 1 & - & 2 & - & - & 1 \\
\hline Unidentifiable seeds & & ct & 33 & 9 & 60 & 5 & 21 & 5 & 4 & 3 & 16 & 2 \\
\hline $\begin{array}{l}\text { Total identified to } \\
\text { genus }\end{array}$ & & ct & 136 & 7 & 88 & 104 & 108 & 2 & 4 & 160 & 104 & 57 \\
\hline $\begin{array}{l}\text { Total identified to } \\
\text { family }\end{array}$ & & ct & 149 & 8 & 95 & 107 & 109 & 2 & 6 & 226 & 107 & 67 \\
\hline $\begin{array}{l}\text { Salix sp. wood } \\
\text { charcoal }\end{array}$ & & $\mathrm{mg}$ & 830.8 & - & - & - & - & - & - & - & - & - \\
\hline $\begin{array}{l}\text { Unidentified wood } \\
\text { charcoal }\end{array}$ & & $\mathrm{mg}$ & 247.2 & 0.6 & - & 2.3 & 5.7 & - & - & - & 275.0 & - \\
\hline
\end{tabular}

388 Extended Data Table 1. Charred plant materials from the Wishbone site (42TO6384) and paleoenvironmental control samples. 


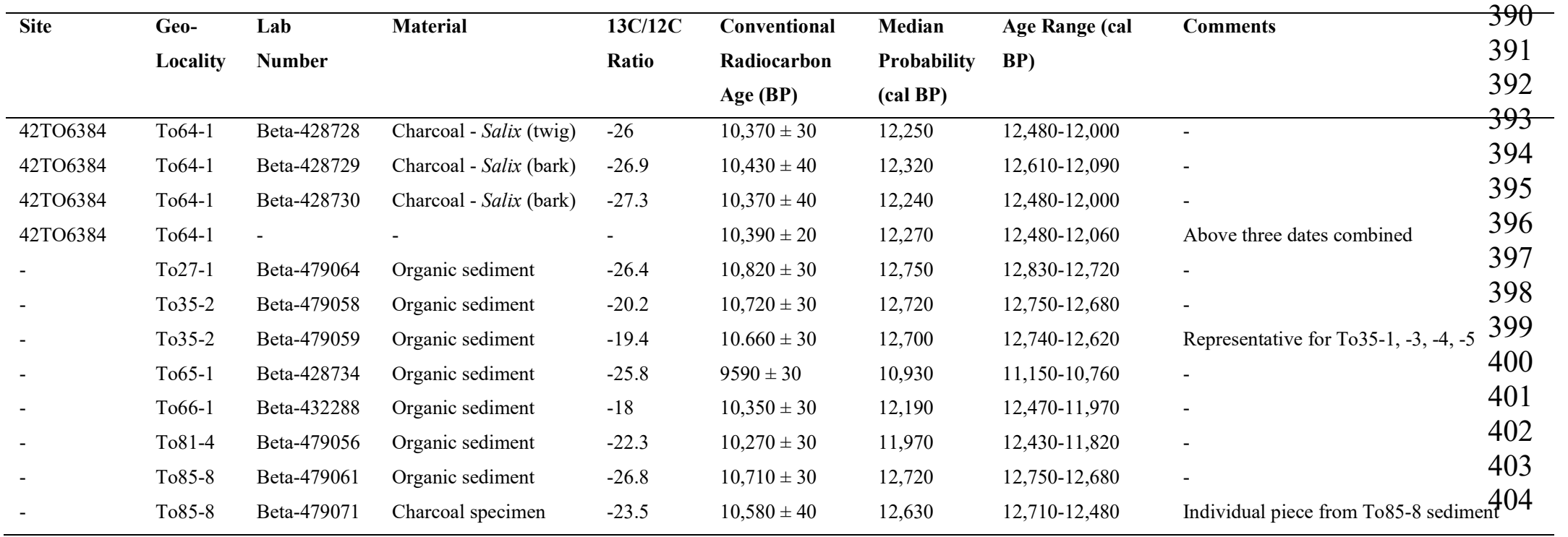

405 Extended Data Table 2. Radiocarbon age estimates from Feature 1 at the Wishbone site (42TO6384) and paleoenvironmental 406 controls. Calibrations using OxCal 4.4, 2 $\sigma$ SD. Ages rounded to the nearest 10 years. 


\section{Acknowledgements}

408 We thank the United States Air Force for support of this work, especially Jaynie Hirschi, 409 Anya Kitterman, and Michael Shane. We also appreciate the assistance and field support of U.S. 410 Army Dugway Proving Ground archaeologists Jennifer DeGraffenried and Nate Nelson. Mark

411 Slaughter, Bureau of Reclamation, and Leilani Lucas, College of Southern Nevada, provided 412 valued feedback. Numerous others deserve more credit than space will allow for their devoted

413 fieldwork, insightful thoughts, and generous assistance. We thank you. The work was funded 414 through a Research Subaward Agreement (PG16-24878-01) to Far Western Anthropological 415 Research Group by the Center for Integrated Research on the Environment, University of 416 Montana, under Contract No. W9128F-14-2-0002 TO 12 with the United States Army Corps of 417 Engineers, Omaha District. The Air Force publication authorization case number for the current 418 study is 75ABW-2019-0014. The Nicotiana specimens collected in this study are currently being 419 stored at Far Western Anthropological Research Group's laboratory in Henderson, Nevada, and 420 will be curated at the Natural History Museum of Utah. 
422 Author Contributions: D.D. directed the project and wrote the main text with assistance

423 from E.W., K.R.A., and S.K.R. E.W. supervised the archaeobotanical laboratory and assisted

424 D.D. with the Methods section. K.R.A. provided specialized knowledge of Nicotiana

425 morphology and human use. A.A-I. initially identified and photographed the Nicotiana seeds in

426 the laboratory. D.D and S.K.R. directed excavations. D.C.Y. conducted geomorphological

427 investigations and directed paleoenvironmental control sampling with D.D. 
429 The data analysed during this study are not currently publicly available but are available 430 upon reasonable request from the corresponding author. They are being processed for curation 431 under accession number UMNH.A.2016.18 at the Natural History Museum of Utah, Salt Lake 432 City, which serves as the repository for archaeological artifacts and related field notes, files, 433 databases, and reporting from military lands managed by Hill Air Force Base. 


\section{Figures}

A

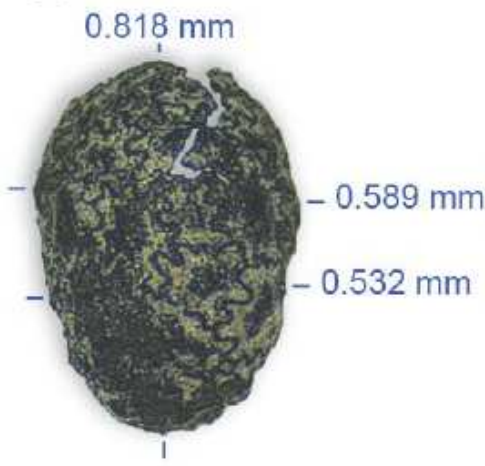

$0.817 \mathrm{~mm}$

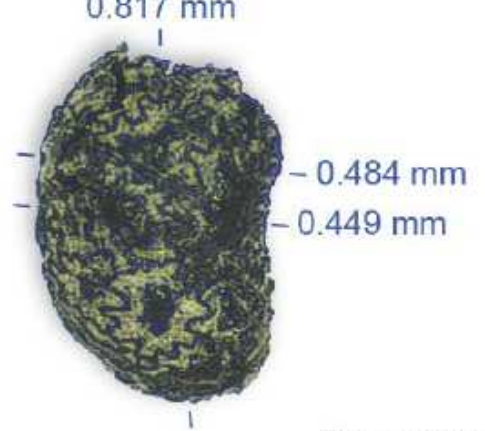

Four views
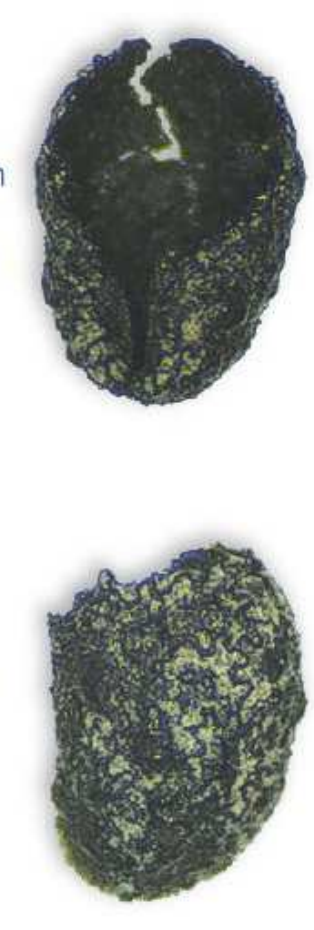$$
\text { (1) }
$$

.
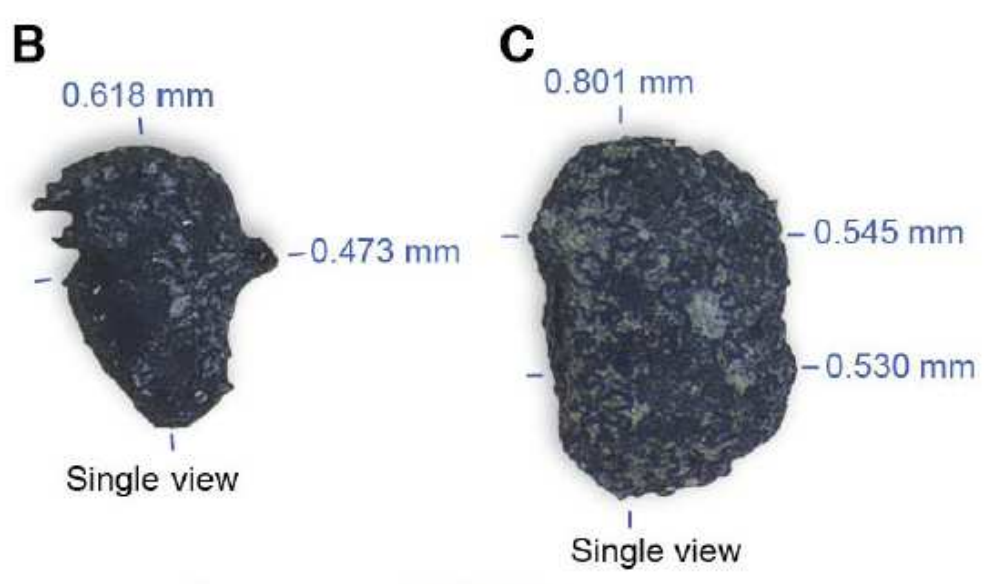

\section{Figure 1}

Nicotiana seeds and measurements from the Wishbone site. (A) Specimen 1-35-98-1. (B) Specimen 1-4098-2. (C) Specimen 1-40-98-1. (D) Specimen 2-40-98-1. 


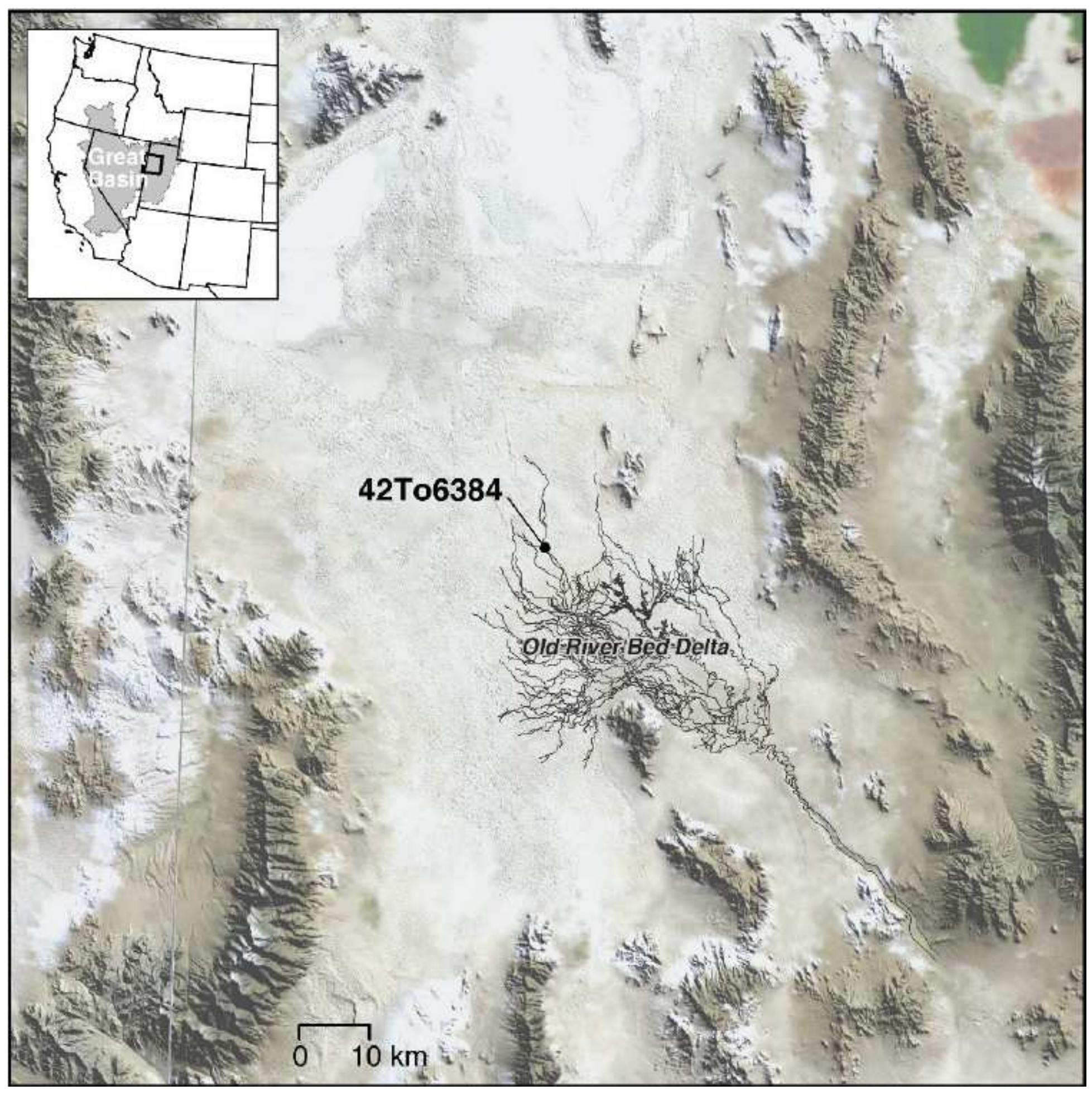

Figure 2

Location of 42T06384 and important physiographic features. The ORBD channels are based on GIS mapping of extant landforms using aerial imagery (courtesy U.S. Army Dugway Proving Ground). 


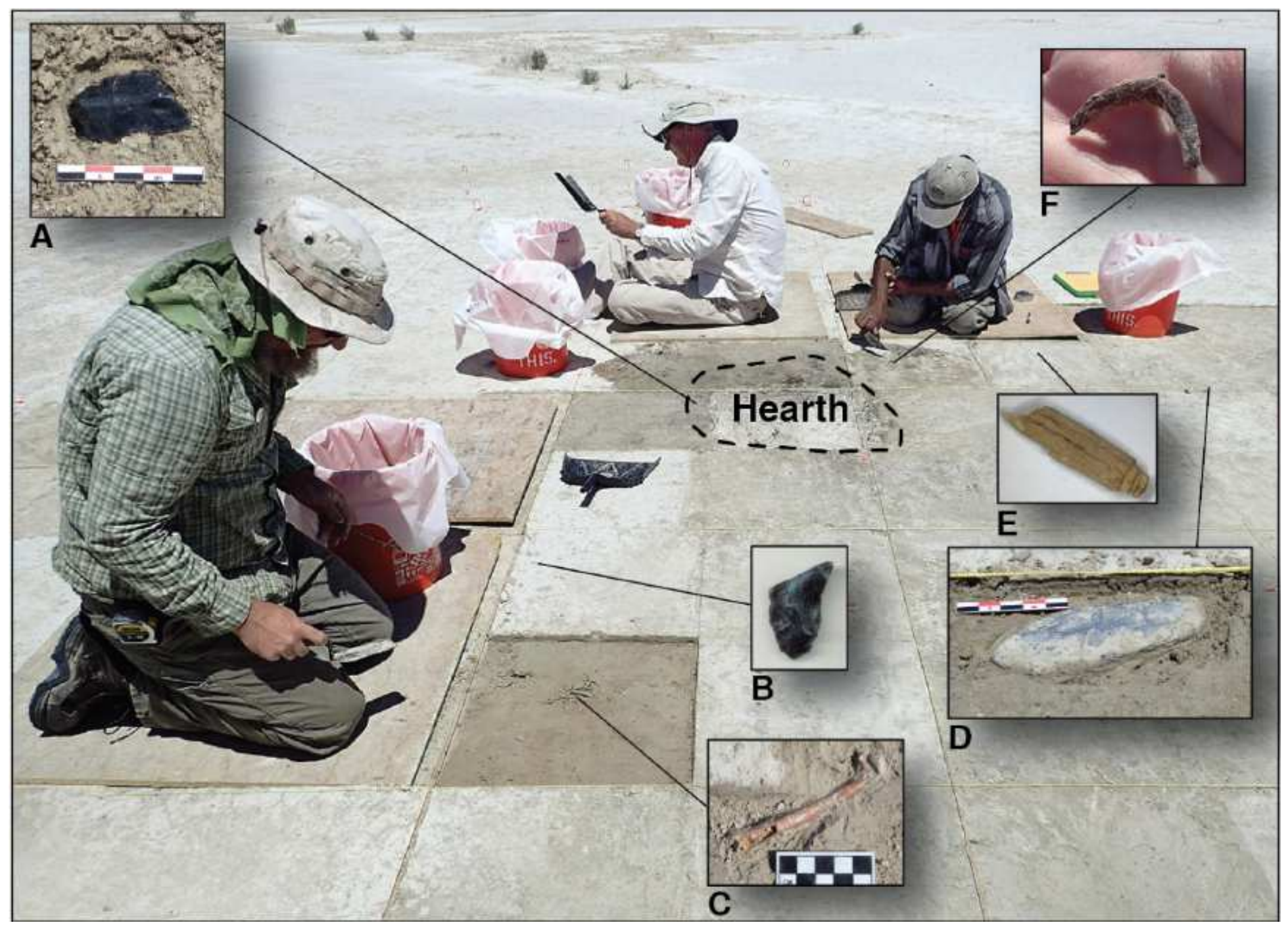

Figure 3

Position of hearth (circled) relative to selected artifacts at the Wishbone site. (A) Haskett fragment, FS 247, refits with FS 59. (B) Haskett fragment, FS 59, refits with FS 247. (C) Anatidae humerus, FS 230. (D) Haskett, FS 220. (E) incised mammal bone, FS 761. (F) Anatidae furculum, FS 230. 


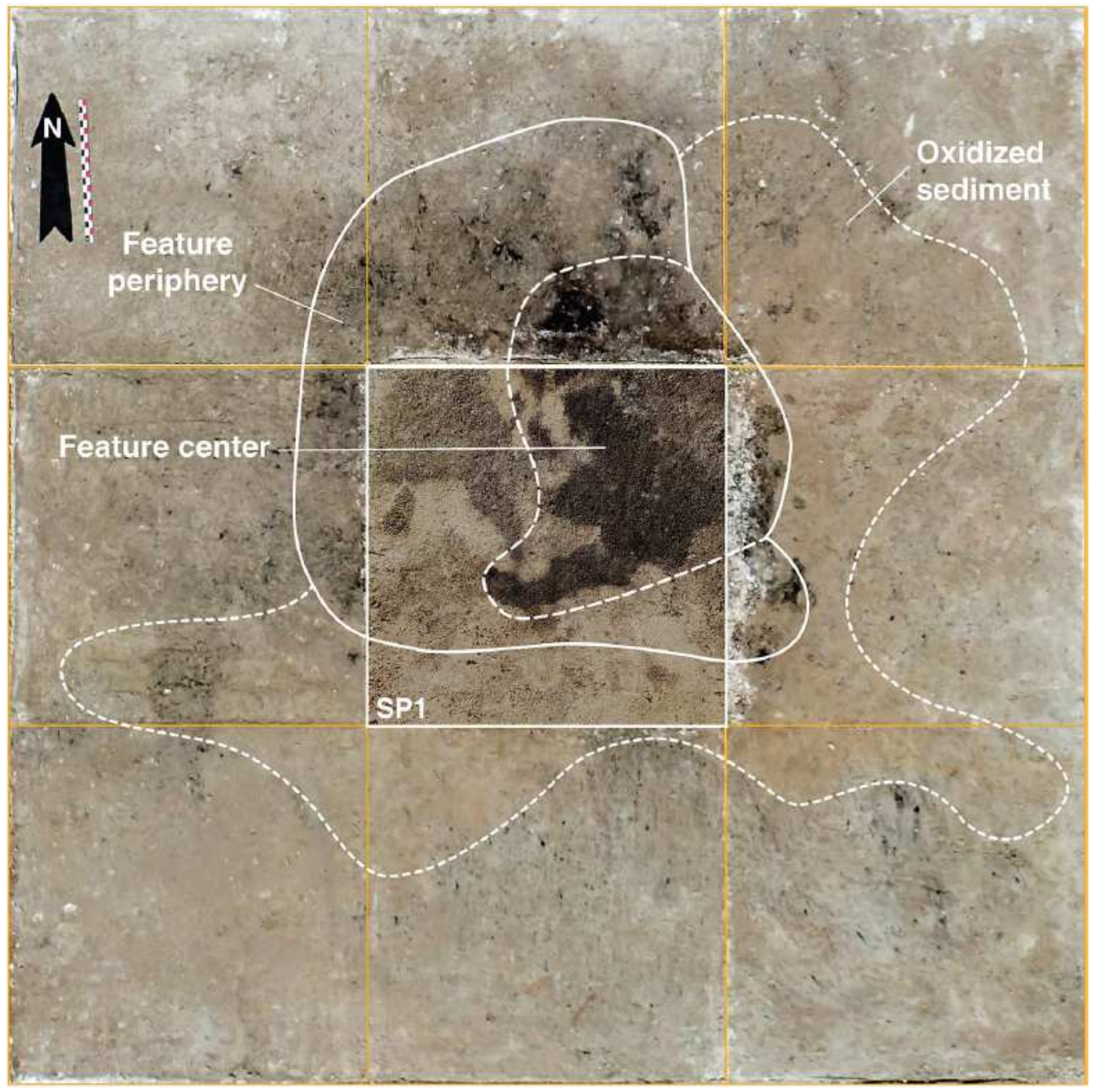

\section{Figure 4}

Hearth (Feature 1) plan view. View is at $2 \mathrm{~cm}$ below the ground surface (162 $\mathrm{cm}$ below datum). Central square represents the $0.5-\mathrm{x}-0.5-\mathrm{m}$ shovel probe (SP1) excavated and photographed in 2015 . The Nicotiana seeds were found in the flotation-processed feature center fill from SP1. Remaining area excavated to the same level and photographed in 2016. Charcoal flecks outside the defined hearth boundary likely represent windblown pieces from the time of use. 